\author{
Marcin Merkwa \\ University of Rzeszów, Poland \\ ORCID: 0000-0001-7288-4552 \\ mmerkwa@ur.edu.pl
}

\title{
The Necessity of the Absolute or Absolute Necessity? On the First Attempts to Search for the Foundations of Natural Rights
}

\author{
Konieczność Absolutu czy absolutna konieczność? O pierwszych \\ próbach poszukiwania podstaw uprawnień naturalnych
}

\begin{abstract}
The basic aim of the article is to prove the thesis that the modern understanding of natural rights is based on considerations initiated in the late Middle Ages, which, focused on the issue of the origin of individual rights, made it possible in the early modern period to connect the idea in question with the issue of the subject. The first part of the paper indicates that for the considerations concerning inalienable rights of the individual, the key issue was to determine their source. The author presents concepts which, to a greater or lesser extent, emphasised not only the role of God, but also the properties of the human being. In particular, attention was paid to the role of the subject in Ockham's theory. These analyses made it possible, in the second part, to show Grotius' work as the fullest expression of the late medieval tradition and to demonstrate that the modern conception of natural rights in its subjective character is based on those doctrines which emphasise the "natural necessity" of the existence of individual rights.
\end{abstract}

Keywords: natural rights; Ockham's theory; Grotius; inalienable rights of the individual

CORRESPONDENCE ADDRESS: Marcin Merkwa, PhD, Assistant Professor, University of Rzeszów, College of Social Sciences, Institute of Legal Studies, Grunwaldzka 13, 35-068 Rzeszów, Poland. 


\section{INTRODUCTION}

The idea of natural rights is one of the most fundamental concepts that have been developed through centuries of reflection on law. It was not (and is not) a homogenous concept. It has taken various forms over the centuries; for example, one can point to the texts of the late Middle Ages, in which theologians and jurists began to use concepts similar to the concept of subjective rights, as well as to contemporary concepts of human rights, which, regardless of whether they are regarded as a continuation of the idea of natural rights, a variation on it or, finally, as a novelty merely based on it, cannot be seen in isolation from it. Both in the Age of Enlightenment, i.e. at the time when the idea of natural rights of the individual was fully expressed, and in the late medieval and early modern periods, i.e. when the philosophical and legal bases of the idea in question began to take shape, one of the most fundamental issues was connected with the question of the origin of natural rights. Do they have a direct source in God (or are they the consequence of divine activity, e.g. the creation of the human being in the image and likeness of God), the law of nature (which could express the divine will or be an order relatively independent of it, and thus binding, at least to a limited extent, the Creator himself), or perhaps in the human being, even if perceived as a created being, we can find that "something" which, defined by "dignity" or "reasonableness", can be considered as the source of inalienable rights?

The basic aim of the discussion carried out in the further part of the article is to prove the thesis that in the analysed periods of the late Middle Ages and early modernity, deliberations were undertaken which led to the formulation of the idea of inalienable rights of the individual. This became possible because the formation of the concept in question, i.e. the recognition of the role of the subject, was connected with the rejection of the connection between God (the law of nature) and the rights which the individual is entitled to. The necessity of the Absolute, mentioned in the title, gives way to "natural necessity". By theories justifying the existence of certain rights in natural necessity, I will mean those concepts which assume that natural rights: (a) are necessary for the functioning of a human being in society, (b) are justified by the structure of man and/or of the world in which he or she lives, and (c) can be considered independently of the assumed existence of God (this condition emphasises not so much the rejection of the causative role of God as the setting aside of the question about it). It should also be added that, although one would like to see naturalness, like D. Dennett does, ${ }^{1}$ as the separation of the concept of natural rights from supernatural elements, when considering the time frame which includes the late Middle Ages and early modernity, it is not pos-

1 D. Dennet, Odczarowanie. Religia jako zjawisko naturalne, transl. and introduction B. Stanosz, Warszawa 2008, p. 50 ff. 
sible, as when considering contemporary concepts, to establish a simple borderline: theistic - non-theistic concepts. It seems reasonable, when speaking of naturalness, to include in the group of ideas having a natural justification not only concepts in which the role of God is rejected explicitly (and we will not find many of these, and if we do, such an account is subject to multiple interpretations), but also those in which it is only (or rather as much as) marginalised or omitted. What I have in mind here are these doctrines which make the subject the central category of the concept of natural rights, without explicitly rejecting the causative role of God, i.e. concepts whose authors more or less explicitly assume that natural rights would belong to individuals even if the assumption of the existence of God were rejected. The aim will be achieved by presenting selected late medieval theories, as well as pointing to the role of Grotius, whose work will prove to be extremely important from the perspective of the analysed problem.

\section{THE DEVELOPMENT OF THE BASES OF THE NATURAL RIGHTS CONCEPT}

The concept of natural rights does not appear ex nihilo in the era of the Enlightenment revolutions. And although in contemporary literature there is no lack of attempts to situate the origins of natural rights (and the concept of human rights) ${ }^{2}$ in Greco-Roman antiquity, it seems reasonable to argue that they derive directly from the Enlightenment concept of natural rights, the foundations of which began to take shape in late medieval and early modern thought. It seems essential at this point to recognise that the ways of justifying the concept of natural rights presented later in this article would lead to the development of a "subjective" theory of natural rights, grounded in the subject. A concept which, according to some scholars, would arise not alongside, but in opposition to Thomism. The literature often expresses the view that St. Thomas Aquinas influenced the concept of human rights. J. Finnis wrote that the recognition of rights as something that belongs to the individual brings St. Thomas "one step closer to expressing the idea of human rights". While not rejecting the role and significance of St. Thomas's philosophy for later discussions of natural rights (which is in a sense negative, since the modern projects arose precisely as an attempt to break with, i.a., Thomism), and

2 I leave aside here the question of whether human rights can be equated with the idea of natural rights, and if not, what was/is the relationship between these concepts. For more, see M. Merkwa, U źródet idei praw człowieka. Kształtowanie prawnych i filozoficznych podstaw koncepcji praw człowieka, Lublin 2018, pp. 326-340.

3 J. Finnis, Aquinas' Moral, Political, and Legal Philosophy, [in:] The Stanford Encyclopedia of Philosophy, https://plato.stanford.edu/entries/aquinas-moral-political [access: 30.12.2020]. 
in particular the significance of Thomism or personalism for the development of the twentieth-century concept of human rights (based on the idea of the dignity of the individual), it should be remembered that Thomas Aquinas did not consider the idea of subjective rights, they were not part of his system. ${ }^{4}$ Thomas Aquinas understood ius, so to speak, in a pre-modern way, as that which is right. And rightness was understood as conformity to an objectively existing, divine reality. Ius is thus connected with justice. One can see this particularly clearly, for example, in Thomas's reflections on ownership: de facto a man is only a holder, true ownership belongs to God. And although such an approach to the relationship between God and man will also be central to the most important modern conceptions of natural rights (see J. Locke's conception), nevertheless modern theories have their origins in initially small shifts of emphasis in the first definitions of ius. It were the considerations made, for example, in connection with the Franciscan poverty dispute that would lead to the emergence of the foundations of the idea of natural rights of the individual, it was within the framework of these considerations that, i.a., new definitions of old concepts would be introduced. The problem of the origin of natural rights would also begin to appear in these discussions. The idea that these rights may not derive from a Thomistic understanding of the law of nature, but, for example, from the power that belongs to man, would allow the development of a modern concept of inalienable individual rights, the essence of which would eventually be to break the link between the divine law of nature and natural rights. Events such as the dispute over poverty would make it possible not only to develop certain concepts, but also to lend them a surprisingly practical dimension. Already within the framework of this discussion, the problems that are examined in this thesis were outlined (to a limited extent, of course).

Despite the fact that after the death of St. Francis the popes took different positions on the poverty of monks, all of them had to be based on a certain assumption regarding the origin of ownership (the discussion about rights is actually reduced to a discussion about property rights in this period). Thus, for example, Innocent IV, in 1245, declared it legitimate for Franciscans not to own anything, but John XXII, in 1323, in the bull Ad conditorem, states that the use of things unrelated to the existence of a specific right is an injustice, ${ }^{5}$ which results from the nature of the right of ownership, sanctified by divine law. In this way, rights (obviously occurring as a property right) were bound to the divine order. Such an approach to the right of ownership was common in traditional (Thomistic) conceptions of natural rights. The rejection of such an approach seems to be a contribution to a systematic reflection

4 A.J. Lisska, Aquinas's Theory of Natural Law: An Analytic Reconstruction, New York 2002, p. 228.

5 B. Tierney, The Idea of Natural Rights: Studies on Natural Rights, Natural Law, and Church Law 1150-1625, Cambridge 2001, p. 93 ff. 
on the right of ownership, which would result in the first theories containing new concepts and definitions that would provide the impetus for the later development of the concept of natural rights. From this perspective, a key participant in the discussion of poverty was W. Ockham.

It is worth noting that the significance and role of Ockham in shaping the foundations of the idea of natural rights is assessed very differently. The basic conclusion of B. Tierney's analysis is related to the recognition that Ockham was the one who reconstructed the doctrine of natural rights and built on it the concept of natural rights grounded in nature and reason. However, many authors cite Ockham's thought that "everything done rightly without a right of the forum is done by right of heaven", ${ }^{6}$ and which purports to demonstrate that the grounding of natural laws in reason, attributed to Ockham, is a modern misinterpretation. When citing such formulations, however, it is important to remember that each idea has at least two dimensions: on the one hand, its content is a reflection of what Ockham wanted and tried to express, and on the other hand, there is the concept that Ockham expressed according to his intellectual heirs (these two dimensions may or may not be identical). This reservation is particularly important in the case of authors of the Christian Middle Ages, and also when the subject of analysis is a concept whose development is not of a "leaping" nature, where one cannot speak of breakthroughs, but rather of the accumulation of certain concepts, their different interpretations, and thus of evolution rather than revolution. I think that, with the above reservation in mind, it will not be illegitimate to see Ockham, if not as the creator, then at least as a person, in ways that cannot be overstated, who contributed to the formation of the modern conception of subjective rights. In particular, this is due to the role of the subject in Ockham's theory and the reason of the individual, in which natural rights are grounded. At the same time, the "subjectivity" of rights which human beings are entitled to is related to the inability of individuals to fully understand objective laws - we have the duty (and therefore the right) to follow the voice of conscience, even if it goes against the will of God.

According to V. Mäkinen, the Franciscan debate on poverty had an impact on the development of individual rights in at least two ways. First, the fact that the Franciscans lived without property made it possible to reduce the discussion to the problem of the right of ownership, seen (or not) as a "subjective" right, and therefore belonging to a specific subject. Secondly, the Franciscan demand to reject all rights led to the idea of individual and inalienable rights that belong not only to the poor, but to all individuals in need. For the Franciscan position led to the question of whether the individual could indeed reject all rights that belonged to him or her. This issue was addressed, among others, by G. de Fontibus, who acknowledged the existence,

6 W. Ockham, A Letter to the Friars Minor and Others Writings, eds. A.S. McGrade, J. Kilcullen, Cambridge 2001, p. 54. 
in extreme situations, of rights enjoyed by people which are impossible for them to waive. This doctrine, which had been known in medieval theology and canon law since the end of the $12^{\text {th }}$ century, was made more precise by Godfrey, who decided that because the individual had a duty to preserve his or her life, in extreme situations he or she was entitled, under the law of nature, to a dominion and a certain right to common external goods. This was probably the first formulation of the individual right to subsistence. ${ }^{7}$ Ockham argued in a similar way. S. Van Duffel wrote that Ockham's claim according to which people have a natural right to take whatever steps are necessary to enable them to save their own lives was an affirmation of what appears to be the communis opinio of jurists and theologians of the period, a view that was virtually unchallenged until the second half of the $17^{\text {th }}$ century. ${ }^{8}$

The above remarks about the origins of the formation of natural rights are not intended to show that the concept was propounded at the time. However, it was, i.a., the discussion on poverty (and perhaps it was this discussion above all) that provided the impetus for the development of a new language through which the modern concept of natural rights would become possible. From the perspective of the subject of this article, it is worth noting that, from the very beginning, the development of the idea under discussion seems to lead in the direction of rejecting the "necessity of the Absolute" (of course, I do not mean here an intentional process). This is primarily because in the legal and philosophical discourse (although, as an aside, one should ask whether such a separation was possible at that time) a process of distinguishing between the different meanings of the term ius began.

While this term was associated in the tradition of Greco-Roman antiquity (in particular in Roman law), or in Thomas Aquinas's works, with objectively existing justice, in the emerging concept it began to be associated with the power enjoyed the subjects of law. Marsilius of Padua played a particularly important role in coining this understanding of ius. Unlike Thomas Aquinas - who remained within the Stoic tradition of law" - rejects it, concluding: "Thus in one sense ius is the same as lex, divine or human. [...] In a second way ius refers to any voluntary human act, power, or habit". ${ }^{10}$

The language that began to emerge from the work of thinkers of the period in question, however, needed to be generalised; in this field, particular credit is

7 V. Mäkinen, The Franciscan Background of Early Modern Rights Discussion: Rights of Property and Subsistence, [in:] Moral Philosophy on the Threshold of Modernity, eds. J. Kraye, R. Saarinen, Dordrecht 2005, pp. 176-178.

8 S. Van Duffel, J. Robinson, Ockham' Theory of Natural Rights, http://individual.utoronto.ca/ jwrobinson/articles/vanduffel-robinson_ockhams-theory-of-natural-rights.pdf [access: 10.09.2021], p. 23.

9 L. Dubel, Koncepcja władzy prawodawczej Marsyliusza z Padwy, [in:] Konstytucyjny ustrój państwa. Księga jubileuszowa Profesora Wieslawa Skrzydly, eds. T. Bojarski, E. Gdulewicz, J. Szreniawski, Lublin 2000, p. 54.

${ }^{10}$ As cited in B. Tierney, op. cit., p. 109. 
attributed to J. Gerson, whose concept, based on the recognition of a right as an ability or power, is, according to some scholars, "the first true natural rights theory". ${ }^{11}$ The ideas of the late medieval period, despite occasional references to what today we would call universal rights, are connected with the solution of specific problems (Ockham defends the doctrine of poverty, Marsilius opposes the papacy). This is not, of course, an accusation against these theories, but merely a statement of the fact that it is difficult to find not only an answer to the question in the title of the article, but also its very expression, in late medieval deliberation directed at practical issues. It seems that the question as to whether possible natural laws are a necessary element of the natural order, or whether their existence necessarily presupposes the existence of the Absolute, became the subject of in-depth analysis only in the works of modern thinkers such as H. Grotius, T. Hobbes or J. Locke, which, however, (and this is always worth reminding) are closely related to the findings of late medieval thinkers. This is particularly so because the body of work of Spanish scholasticism, which is sometimes seen as the bridge over which the ideas of the late Middle Ages (and above all the language in which they began to be expressed) "passed" into modernity, although significant, is based (in principle) on an affirmation of the relationship between natural rights and God as something self-evident and unquestionable. As an example, it may be pointed out that F. Vitoria, when demonstrating the subjectivity of American Indians, saw its source not in his contemporary humanist tradition, but in his understanding of man as the culmination of creation. B. Las Casas, who according to some researchers formulated the concept of universal natural rights (others claim that he was merely developing the scholastic legacy), considers liberty to be a natural right of all human beings, linked to their innate rationality, which has its source in the fact that all human beings have been created in the image and likeness of God.

\section{THE IMPIOUS HYPOTHESIS - THE SUBJECT AS A SOURCE OF RIGHTS}

The scope for consideration of natural rights was very limited for Renaissance humanists. This was due to the impossibility of accepting a justification that would refer to something other than codified law. If ownership did not exist in the state of nature, ${ }^{12}$ then all rights had a source in civil law. The reflection on rights was concentrated above all in the area of their civil law bases.

11 J. Quillet, Community, counsel and representation, [in:] The Cambridge History of Medieval Political Thought c. 350 - c. 1450, ed. J.H. Burns, New York 2008, p. 511.

${ }^{12}$ François Connan, when writing about the use of things expressed it with the following words: "[...] and that this use is very like dominium: but it is not dominium" (as cited in R. Tuck, Natural Rights Theories: Their Origin and Development, Cambridge-New York-Oakleigh 2002, p. 40). 
Hence it can be assumed that before the $17^{\text {th }}$ century, before the key concepts of the revolutionary era, we have two traditions of considering the problem of natural rights. ${ }^{13}$ The first is the tradition of humanistic jurists who reject this concept, taking for granted the antinomy between civilisation and barbaric life; the reflection on natural rights is impossible because such a thing simply does not exist - rights are not natural, they are, so to speak, human, and have their source only in codified law. The second tradition is related to the activity of jurists and philosophers of the late Middle Ages, which initially aimed at solving very specific problems (e.g., the problem of the poverty of monks), and it was reflected in the doctrine of Spanish scholasticism, which, although occasionally was close to universalism, also concentrated on practical issues. For the representatives of the second group, especially the problem of justifying the existence of natural rights (ownership in particular), although weighty, could be reduced in essence to the conclusion that they have their source in the fact that God created, in his image and likeness, a rational subject. And although it was the Spanish scholasticism that provided a contribution to the development of the idea in question that is difficult to overestimate (and it can also be argued that without Iberian thinkers the concept would not have made its way into modern considerations), it seems that fully developed concepts of natural rights arose as an attempt to break with earlier ways of justifying them and as such were born on the basis of Protestant theories.

Spanish scholasticism attempted a kind of fusion of the Renaissance understanding of ownership with the doctrine of the late Middle Ages, in which ownership played a key role (whether as a natural institution given by God or as a creation appearing after the fall), the idea of natural law and Aristotelianism (albeit in different, sometimes very "non-Aristotelian" interpretations). The key of Protestant theories was the rejection of the foundation of scholastic concepts, i.e. the ability of man to have an incomplete, often erroneous (see Ockham), but nevertheless possible understanding of God and his creation. By emphasising faith and a kind of "discontinuity" between God and his creation, Protestants allowed secular concepts of natural rights to develop. Concepts that could, in a sense, be called truly subjective. Truly, because in them the source of rights will be the very subject. Obviously, this does not mean that the idea of God does not appear in these reflections or does not sometimes play a significant role. "Between the two worlds [the world of Catholic medieval theologians and jurists developing ideas of natural rights and the world of Protestant thinkers] linking them together"14 is the figure of Grotius, who made possible the works of Hobbes or Locke in which a "real breakthrough in the understanding of nature and its laws was made, giving rise to consequences

${ }^{13}$ M. Freeman, Prawa człowieka, transl. M. Fronia, Warszawa 2007, p. 27.

${ }^{14}$ B. Tierney, op. cit., p. 316. 
that reach into some contemporary schools of natural law". ${ }^{15}$ In De jure praedae, the first part of which, Mare Liberum, was published in 1609, Grotius stated that "what God has shown to be His Will, that is law", ${ }^{16}$ but then attempted to present what the divine will is through the lens of man's social nature, which would become the basis for later secular theories. The thinker's theory, with the practical task of demonstrating freedom of action on the seas, links freedom, the central category of his concept, to ownership: "For what is that well-known concept, 'natural liberty', other than the power of the individual to act in accordance with his own will?". ${ }^{17}$

Rejecting humanist beliefs about the origin of ownership, but also the scholastic recognition of the existence of a natural dominium, Grotius concludes that in the primordial state people were entitled to certain rights (in particular to things), and although they were not identical to the modern thinkers' conception of ownership, they were not completely different from it either. This position, expressed in De jure praedae, is somewhat mitigated (in the direction of scholastic concepts) in De jure belli (this clearly shows the place of the thinker at the borderline of the Middle Ages and modernity).

Grotius presented a relatively large number of definitions of rights, definitions that reflect the tradition of the late Middle Ages, the work of the Spanish Scholastics, but also refer to authors from antiquity (in whose works, however, one searches in vain for similar considerations); it is from these that emerges what is seen in the literature as "Grotius's greatest contribution". ${ }^{18}$ According to K. Haakonssen, Grotius' innovativeness is related to the detachment, the complete "subjectification" of rights: they become detached from natural law in the sense that the necessary condition for their existence is no longer conformity to it. Obviously, Grotius' role and significance were and continue to be evaluated in very different ways. Among other things, the question arises as to whether natural rights were to replace natural law, or are they simply two orders coexisting with each other? However, it is a rather common view that from the time of Grotius onwards we can speak of the secularisation of the concept in question. It seems that it was what R. Tuck calls the emphasis on the "non-theistic" character ${ }^{19}$ that allowed modern conceptions of natural rights to develop. In Grotius's doctrine, rooted in the scholastic tradition, ius ceases to be associated with natural law, it becomes something that the individual has - thus a "subjectification" of a right takes place, the essence of this

${ }^{15}$ M. Jaskólski, Organizm a mechanizm. Zmienność pojęcia natury i jej praw, [in:] 13 różnych esejów, Warszawa 2013, p. 150.

${ }^{16}$ H. Grotius, Commentary on the Law of Prize and Booty, transl. G.L. Williams, vol. 1, Oxford-London 1950, p. 19.

17 Ibidem, p. 33.

${ }_{18}$ K. Haakonssen, Hugo Grotius and the History of Political Though, "Political Theory" 1985, vol. 13(2), p. 240.

${ }^{19}$ R. Tuck, op. cit., p. 76. 
process being to place the subject at the centre of the theory of rights. In this view, ius becomes a power or moral qualification of the individual.

When writing about this "non-theistic" character, one usually points to the so-called "impious hypothesis", according to which "the Law of Nature is so unalterable, that God himself cannot change it. For tho' the Power of God be infinite, yet we may say, that there are some Things to which this infinite Power does not extend, because they cannot be expressed by Propositions that contain any Sense, but manifestly imply a Contradiction. For Instance then, as God himself cannot effect, that twice two should not be four; so neither can he, that what is intrinsically Evil should not be Evil". ${ }^{20}$

The hypothesis according to which natural law is valid even if we assume "that God does not exist or that He does not care about human affairs was a source of controversy even among thinkers positively disposed towards Grotius' work, such as Pufendorf. The matter was clarified by the thinker in a letter addressed to his brother, in which Grotius writes that God could have created man - he was completely free in this matter. However, once the decision to create was made, God out of necessity had to take actions that were consistent with nature and reject those that were contrary to it. Although many of God's commands and prohibitions occur not because they were necessary, but because God wanted to establish them, in making the free decision to create man God had to accept that certain rules were necessary for human functioning - In other words, it is not conceptually possible to envisage a rational social being to whom the laws of nature do not apply". ${ }^{21}$

The hypothesis, often seen as, already present in scholastic discourse, a topos that Grotius may have taken, for example, from Suárez, ${ }^{22}$ can be considered as the moment from which we can already speak of natural rights as "natural necessity", i.e. an idea that, although perhaps not definitively, but at least to a very significant degree, is detached from its theological sources. However, such a thesis requires two reservations. First, the statement "from that point onwards" must be seen as an extreme simplification. As mentioned above, in the development of the idea of natural rights before the period of the Enlightenment revolutions, as in the development of most ideas, there are generally no moments from which something begins in an unambiguous way. With hindsight, it is relatively easy to attempt to identify a turning point marking the incompatibility of concepts developed before and after it. However, in the case of the concept of natural rights, the recognition of the aforementioned moment as a breakthrough is only symbolic and results above all from the fact that it can be assumed that every thinker who in the $17^{\text {th }}$ century

${ }^{20}$ H. Grocjusz, Trzy księgi o prawie wojny i pokoju, transl. and introduction R. Bierzanek, Warszawa 1957, p. 93.

${ }^{21}$ R. Tuck, op. cit., p. 76.

${ }^{22}$ B. Tierney, op. cit., pp. 319-320. 
addressed the issue of natural rights had to face the legacy of Grotius (which was also necessitated by the fact that his system contained many inaccuracies). Second, one must remember that assessing the works of a given thinker requires attention to the roles in which he or she acted. As M.B. Crowe writes, ${ }^{23}$ Grotius-the theologian had no intention to separate natural law from theology. F. Copleston has a similar view and writes that "it may be true to say that, being a historical fact, Grotius's treatment of the idea of natural law contributed to the 'naturalisation' of that idea to the extent that he treated law not as a theologian but as a jurist and legal philosopher. However, it is a mistake to suggest that Grotius made a radical break with the position of, say, Thomas Aquinas [...] Grotius's 'modernity', his careful and systematic treatment of law from the point of view of a secular jurist and philosopher, is what gives the impression that he made a greater break with the past than he actually did". ${ }^{24}$

\section{CONCLUSIONS}

Even if Grotius' "break with the past" was not, as F. Copleston claims, as great as it may seem, there is no doubt that thanks to him it could become complete in the near future. A century later, the following words would become Hobbes' programme and philosophical declaration: ${ }^{25}$ "The RIGHT OF NATURE, which Writers commonly call Jus Naturale, is the Liberty each man hath, to use his own power, as he will himself, for the preservation of his own Nature; that is to say, of his own Life; and consequently, of doing any thing, which in his own Judgement, and Reason, he shall conceive to be the aptest means thereunto". ${ }^{26}$

Natural rights would be for Hobbes (at least in the state of nature) absolute, i.e. limited only by the ability to enforce them. ${ }^{27}$ They would be contrasted with the law of nature, which would be seen as the limitation of natural individual liberty. Hobbes would see liberty as the essence of the right, while natural law would appear as its complete opposite. ${ }^{28}$ Liberty would become the core of natural rights,

${ }_{23}$ M.B. Crowe, The "Impious Hypothesis": A Paradox in Hugo Grotius?, "Tijdschrift voor Filosofie" 1976, no. 3.

${ }^{24}$ F. Copleston, Historia filozofii, vol. 3: Od Ockhama do Suáreza, transl. H. Bednarek, S. Zalewski, Warszawa 2001, pp. 350-351.

${ }^{25}$ S. Goyard-Fabre, Metamorphosis of the Idea of Right in Thomas Hobbe's Philosophy, [in:] Hobbes's 'Science of Natural Justice', eds. C. Walton, P.J. Johnson, Dordrecht-Boston-Lancaster 1987, p. 153 ff.

${ }_{26}$ T. Hobbes, Lewiatan, czyli materia, forma i władza państwa kościelnego i świeckiego, transl.

C. Znamierowski, Warszawa 2009, I, XIV, I, pp. 210-211.

${ }^{27}$ I. Shapiro, The Evolution of Rights in Liberal Theory, New York 1986, p. 43.

${ }^{28}$ T. Hobbes, op. cit., XIV, 3, p. 211. 
and in virtually all modern concepts, a way out of the state of nature would require the creation of institutions to secure natural rights. In such a view, natural rights find their source in, broadly understood, natural necessity, and social organisations are based on the natural structure of the individual, of which natural rights are its essence. In such concepts, rights are truly subjective. Such an approach to the problem makes it possible to acknowledge the correctness of the thesis posed at the beginning of the article: the development of the idea of natural rights was possible thanks to the concepts which began to be proclaimed in the late medieval period. The thinkers of this period not only developed a new language, gave new definitions to old concepts, but above all created the basis for the development of the concept, which did not become just a simple development of the doctrine of the law of nature.

\section{REFERENCES}

\section{Literature}

Copleston F., Historia filozofii, vol. 3: Od Ockhama do Suáreza, transl. H. Bednarek, S. Zalewski, Warszawa 2001.

Crowe M.B., The "Impious Hypothesis": A Paradox in Hugo Grotius?, "Tijdschrift voor Filosofie" 1976, no. 3.

Dennet D., Odczarowanie. Religia jako zjawisko naturalne, transl. and introduction B. Stanosz, Warszawa 2008.

Dubel L., Koncepcja władzy prawodawczej Marsyliusza z Padwy, [in:] Konstytucyjny ustrój państwa. Ksiega jubileuszowa Profesora Wieslawa Skrzydly, eds. T. Bojarski, E. Gdulewicz, J. Szreniawski, Lublin 2000.

Freeman M., Prawa człowieka, transl. M. Fronia, Warszawa 2007.

Goyard-Fabre S., Metamorphosis of the Idea of Right in Thomas Hobbe's Philosophy, [in:] Hobbes's 'Science of Natural Justice', eds. C. Walton, P.J. Johnson, Dordrecht-Boston-Lancaster 1987.

Grocjusz H., Trzy ksiegi o prawie wojny i pokoju, transl. and introduction R. Bierzanek, Warszawa 1957.

Grotius H., Commentary on the Law of Prize and Booty, transl. G.L. Williams, vol. 1, Oxford-London 1950.

Haakonssen K., Hugo Grotius and the History of Political Though, "Political Theory" 1985, vol. 13(2).

Hobbes T., Lewiatan, czyli materia, forma i władza państwa kościelnego i świeckiego, transl. C. Znamierowski, Warszawa 2009.

Jaskólski M., Organizm a mechanizm. Zmienność pojęcia natury i jej praw, [in:] 13 różnych esejów, Warszawa 2013.

Lisska A.J., Aquinas's Theory of Natural Law: An Analytic Reconstruction, New York 2002.

Mäkinen V., The Franciscan Background of Early Modern Rights Discussion: Rights of Property and Subsistence, [in:] Moral Philosophy on the Threshold of Modernity, eds. J. Kraye, R. Saarinen, Dordrecht 2005.

Merkwa M., Uźródet idei praw człowieka. Kształtowanie prawnych i filozoficznych podstaw koncepcji praw człowieka, Lublin 2018. 
Ockham W., A Letter to the Friars Minor and Others Writings, eds. A.S. McGrade, J. Kilcullen, Cambridge 2001.

Quillet J., Community, counsel and representation, [in:] The Cambridge History of Medieval Political Thought c. $350-$ c. 1450, ed. J.H. Burns, New York 2008.

Shapiro I., The Evolution of Rights in Liberal Theory, New York 1986.

Tierney B., The Idea of Natural Rights: Studies on Natural Rights, Natural Law, and Church Law 1150-1625, Cambridge 2001.

Tuck R., Natural Rights Theories: Their Origin and Development, Cambridge-New York-Oakleigh 2002.

\section{Online sources}

Finnis J., Aquinas' Moral, Political, and Legal Philosophy, [in:] The Stanford Encyclopedia of Philosophy, https://plato.stanford.edu/entries/aquinas-moral-political [access: 30.12.2020].

Van Duffel S., Robinson J., Ockham'Theory of Natural Rights, http://individual.utoronto.ca/jwrobinson/articles/vanduffel-robinson_ockhams-theory-of-natural-rights.pdf [access: 10.09.2021].

\section{ABSTRAKT}

Podstawowym celem artykułu jest dowiedzenie tezy, zgodnie z którą u podstaw nowożytnego rozumienia praw naturalnych znajdują się rozważania zapoczątkowane w późnym średniowieczu, które - skupione na problemie pochodzenia uprawnień jednostki - pozwoliły we wczesnej nowożytności związać omawianą ideę z problemem podmiotu. W pierwszej części wskazano, że dla rozważań dotyczących niezbywalnych praw jednostki kluczową kwestią było określenie ich źródła. Ukazane zostały koncepcje, które w mniejszym lub większym stopniu akcentowały nie tylko rolę Boga, ale i właściwości człowieka. W szczególności uwagę zwrócono na rolę podmiotu w teorii Ockhama. Analizy te pozwoliły ukazać w drugiej części opracowania dorobek Grocjusza jako najpełniejszy wyraz późnośredniowiecznej tradycji oraz wykazać, że nowożytna koncepcja uprawnień naturalnych w swym subiektywnym charakterze opiera się na tych doktrynach, które akcentują ,naturalną konieczność" istnienia praw jednostki.

Slowa kluczowe: uprawnienia naturalne; teoria Ockhama; Grocjusz; niezbywalne prawa jednostki 